DOI: 10.14720/aas.2016.107.1.11

Agrovoc descriptors: osmotic stress; calcium fertilizers; fertilizer application; varieties; defence mechanisms; proline; tropical crops; phoenix dactylifera

Agris category code: F04, f40, f62

\title{
Calcium application mitigates salt stress in Date Palm (Phoenix dactylifera L.) offshoots cultivars of Berhi and Sayer
}

\author{
Abbas M. JASIM ${ }^{1}$; Muayed F. ABBAS ${ }^{2}$; Hussein J. SHAREEF ${ }^{3}$
}

Received September 20, 2015; accepted November 16, 2015.

Delo je prispelo 20. septembra 2015, sprejeto 16. november 2015.

\begin{abstract}
The effectiveness of exogenous application of calcium in ameliorating the adverse effects of salt stress $\left(15.9 \mathrm{dS} \mathrm{m}^{-1}\right)$ on date palm offshoots (Phoenix dactylifera L. cultivars of Berhi and Sayer) was investigated. Ca-fertilisers Polixal and Rexene were applied either as soil amendments or foliar spray. The results showed that Polixal at $30 \mathrm{ml}_{\text {offshoot }}{ }^{-1}$ significantly increased plant height, leaf area, total chlorophyll content, RWC, proline concentration, peroxidase activity, IAA content, $\mathrm{K}^{+}$and $\mathrm{K}^{+} / \mathrm{Na}^{+}$ratio in leaves of Berhi cultivar, whereas catalase activity, $\mathrm{ABA}$ and $\mathrm{Cl}^{-}$content were decreased. Also Berhi cultivar responded to soil amendments more than to foliar spray. However, Ca-fertilisers mitigated salt stress in the two cultivars and Berhi cultivar was more salt stress tolerant than Sayer cultivar by maintaining the high ratio of $\mathrm{K}^{+} / \mathrm{Na}^{+}$ and regulating levels of IAA to ABA, in silty clay loam soil. These results suggest that calcium application can improve the defense system under salt stress conditions.
\end{abstract}

Key words: antioxidant enzymes, Date Palm, salt stress, IAA, ABA, calcium application, proline, RWC

\section{IZVLEČEK}

DODAJANJE KALCIJA ZMANJŠUJE SLANOSTNI STRES PRI KOKOSOVI PALMI (Phoenix dactylifera 'Berhi' IN 'Sayer')

Pri dveh sortah kokosove palme (Phoenix dactylifera 'Berhi' in 'Sayer') je bil preučevan blažilni učinek dodajanja kalcija na negativne učinke slanostnega stresa $\left(15.9 \mathrm{dS} \mathrm{m}^{-1}\right)$. Cagnojili Polixal in Rexene sta bili dodajani ali kot talni dodatek ali kot listno pršilo. Rezultati so pokazali, da je dodatek Polixal-a v količini $30 \mathrm{ml}$ na rastlino značilno povečal višino rastlin, listno površino, vsebnost celokupnega klorofila, relativno vsebnost vode (RWC), vsebnost prolina, aktivnost peroksidaze, vsebnost IAA in $\mathrm{K}^{+}$ter razmerje $\mathrm{K}^{+} / \mathrm{Na}^{+} \mathrm{v}$ listih sorte Berhi, aktivnost katalaze, vsebnost $\mathrm{ABA}$ in $\mathrm{Cl}^{-}$so se zmanjšali. Sorta Berhi se je bolje odzvala na dodatek gnojil v tla kot na foliarna gnojila. Calcijeva gnojila so pri obeh sortah zmanjšala slanostni stres na bogatih peščeno-ilovnatih tleh, vendar se je sorta Berhi izkazala nanj odpornejša kot sorta Sayer saj je ohranjala večje $\mathrm{K}^{+} / \mathrm{Na}^{+}$razmerje, kar je izboljšalo tudi razmerje med IAA in ABA. Rezultati te raziskave nakazujejo, da gnojenje s Ca izboljša obrambni sistem rastlin $\mathrm{v}$ razmerah slanostnega stresa.

Ključne besede: antioksidacijski encimi, dateljeva palma, slanostni stres, IAA, ABA, gnojenje s $\mathrm{Ca}$, prolin, RWC

\section{INTRODUCTION}

Inhibition of plant growth by high amounts of $\mathrm{Na}^{+}$ and $\mathrm{Cl}^{-}$is one of the main deleterious effects of salt stress. When present in excess amount, $\mathrm{Na}^{+}$ and $\mathrm{Cl}^{-}$ions enter into plant cells and can exert toxic effects on cell membranes and metabolic activities in the cytosolic part of the cell (Hasegawa et al. 2000; Zhu, 2001; Türkan and Demiral, 2009). The resultant effect of osmotic

\footnotetext{
Department of Horticulture and Landscape Design, College of Agriculture, University of Basrah, Basrah, Iraq, abbasjasim5@yahoo.com

2 Department of Horticulture and Landscape Design, College of Agriculture, University of Basrah, Basrah, Iraq, muayedfadhil@yahoo.co.uk

3 Department of Date Palm Varieties, Date Palm Research Centre, University of Basrah, Basrah, Iraq, husseinshareef@live.com
} 
stress and ionic toxicity may lead to secondary effects in plants such as decreased cell expansion, production of assimilate and membrane functions, decreased cytosolic metabolism with raised production of ROS, including singlet oxygen $\left({ }^{1} \mathrm{O}_{2}\right)$, superoxide $\left(\mathrm{O}_{2}^{-}\right)$, hydroxyl radical $(\mathrm{OH})$ and hydrogen peroxide $\left(\mathrm{H}_{2} \mathrm{O}_{2}\right)$ (Lindberg et al., 2012). Calcium plays a fundamental role in plant growth and development. Many extracellular signals and environmental cues including light, abiotic and biotic stress factors, elicit change in the cellular calcium levels, termed as calcium signatures ( $\mathrm{Wu}$ et al., 2013). Calcium ions ameliorate the effect of salt stress by competing with sodium ions for membrane-binding sites. Salt stress reduces N, P, $\mathrm{K}$, and $\mathrm{Ca}$ content in tissues; however, the addition of $\mathrm{Ca}$ restored the levels of these nutrients. In general, as external $\mathrm{Ca}^{2+}$ concentrations increase, $\mathrm{Na}^{+}$uptake and concentrations decrease while $\mathrm{Ca}^{2+}$ uptake and concentrations increase because $\mathrm{Ca}^{2+}$ interferes with non-selective cation channels and restricts $\mathrm{Na}^{+}$uptake. In addition, as the salt concentration in the root zone increases, the requirement for $\mathrm{Ca}^{2+}$ increases. However, the uptake of $\mathrm{Ca}^{2+}$ from the soil may be reduced as a result of ion interactions, precipitation, and increased ionic strength. These factors reduce the activity of $\mathrm{Ca}^{2+}$ in solution, which reduces the availability of $\mathrm{Ca}^{2+}$ (Grattan and Grieve 1999, Reddy, 2001 and Louchli and Grattan, 2007). Also, $\mathrm{Na} / \mathrm{Ca}$ interactions can affect growth, photosynthesis, plant nutrition, water and ion transport in plants. The nature of the response will vary depending on the plant genotype (Cramer, 2002).

Zekri and Parsons (1990) found that the addition of 1,5 , or 7.5 , but not $13.5, \mathrm{mM} \mathrm{CaSO}_{4}$ to the saline solution significantly decreased the adverse effect of $\mathrm{NaCl}$ on shoot growth of sour orange seedlings. In salt stressed wheat (Triticum aestivum'Samma') $\mathrm{Ca}^{2+}$ improved plant height and proline content compared with treatment of $90 \mathrm{mM}$ of $\mathrm{NaCl}$ alone (Al-Whaibi et al. 2011). El-Khawaga, (2013) found that the anti-salinity agents as calcium alleviated the adverse effects of salt stress on the growth of Sewy, Zaghloul and Hayany date palm cultivars. Keeping in view all these aspects, a study was planned to test the effectiveness of $\mathrm{Ca}$ fertilisers in alleviating the undesirable effects of salt stress by evaluating morphological, physiological and biochemical attributes change in date palm offshoots cultivars of Berhi and Sayer.

\section{MATERIALS AND METHODS}

\subsection{Field experiment}

The experiment was carried out at the General Authority of Palm station, in Hartha region Basrah, Iraq $\left(30^{\circ} 36.54^{\prime} \mathrm{N} \& 30^{\circ} 38.60^{\prime} \mathrm{N}\right.$ to $47^{\circ} 44.42^{\prime} \mathrm{E}$ to $\left.47^{\circ} 45.18^{\prime} \mathrm{E}\right), 24 \mathrm{~km}$ from center of Basrah, in 2014. 30 uniform, girth $\pm 10 \mathrm{~cm}$ vigorous 4-5 years-old 'Berhi' and 'Sayer' date palm offshoots were used in the experiment. The selected offshoots were planted at $5 \times 5 \mathrm{~m}$ by 15 offshoot for each cultivar. Drip irrigation system was installed. Soil samples were taken from untreated offshoots; also samples of water were taken weekly. Each treatment was replicated three times, with one offshoot for each replicate. The selected offshoots were subjected to spraying foliar and addition to soil treatments to both cultivars at the first week of March as the following:

\subsection{Treatments}

C: Foliar spray of water as control
P1: Soil addition of POLIXAL 20-8* $(15 \mathrm{ml}$ offshoot $^{-1}$ )

P2: Soil addition of POLIXAL 20-8 $(30 \mathrm{ml}$ offshoot $^{-1}$ )

R1: Foliar spray of Rexene ca 10* (1000 ppm offshoot $^{-1}$ )

R2: Foliar spray of Rexene ca 10 (2000 ppm offshoot $^{-1}$ )

\subsection{Ca-fertilisers compounds}

*POLIXAL 20-8: (liquid) $8 \%$ calcium oxide polyhydrocarboxyl (organic acids) $20 \%$ organic material $20 \%$ total nitrogen $4.70 \%$ for alleviation soil salinity and calcium deficiency from Company of ABONOSUALENCIA .co., Spain

* Rexene ca 10: (Solid) Chelated Calcium EDTA $9.7 \%$ Functional Chemicals B.V. AKzoNobel, Mexio. 


\subsection{Average of some Environment factors at field}

Average of electrical conductivity (EC) for soil in study was $15.9 \mathrm{dS} \mathrm{m}^{-1}$, $\mathrm{pH}$ was 8.10. Also, average of water EC was $4.55 \mathrm{dS} \mathrm{m}^{-1}$ and $\mathrm{pH} 7.91$, average of field temperature was $41.6^{\circ} \mathrm{C}$.

\subsection{Parameters of study}

Were taken on October 15; all the physiological measurements were performed as following:

\section{5.1 Parameters of vegetative growth}

\section{5. 1.1 Increase in offshoot height $(\mathrm{cm})$}

Measured by a measuring tape to third fully expanded leaf.

The increase in plant height $=$ plant height when sampling - plant height before treatment

\section{5.1. 2 Leaf area $\left(\mathrm{m}^{2}\right)$}

Leaf area $\left(\mathrm{m}^{2}\right)$ was determined according to Ahmed and Morsy, (1999) in four pinnae taken from the middle parts of each leaf, following the equation:

Leaf area $\left(\mathrm{m}^{2}\right)=(0.37$ (length $\times$ width $)+10.29 \times$ No. of pinnae) / 1000

\subsubsection{Biochemical constituents}

\subsubsection{Total chlorophyll content}

The extraction of total chlorophyll was carried out according to Lichtenthaler and Wellburn, (1983). The fresh tissue of leaves was collected and froze then; the leaves $(0.25 \mathrm{~g})$ were homogenized with $80 \%$ acetone. The optical density (O.D.) of the extracted chlorophyll was measured at 645 and $663 \mathrm{~nm}$ by using spectrophotometer PD-303. Total chlorophyll content was calculated by the following formulae:

Total chlorophyll $(\mathrm{mg} / \mathrm{g})=20.2(\mathrm{OD} 645)+8.02$ (OD 663) x (Vol. / Wt.)

$\mathrm{Vol}=$ the final volume $(\mathrm{ml})$

$\mathrm{Wt} .=$ sample weight $(\mathrm{g})$

\subsubsection{Relative water content (RWC)}

Leaf samples were weighed (fresh biomass) immediately after harvesting, soaked in distilled water at $25^{\circ} \mathrm{C}$ for $24 \mathrm{hr}$ to determine the turgid mass then, the samples were dried in an oven at $80^{\circ} \mathrm{C}$ for $48 \mathrm{hr}$ and their dry biomass was determined. RWC was calculated by the following equation:

RWC $=($ fresh mass- dry mass $) /($ turgid mass- dry mass) x 100 .

2.5.2.3 Determination of proline concentration according to Irigoyen et al., (1992).

\subsubsection{Antioxidant enzyme activity assays}

2.5.3.1 Enzyme extraction after Luhova et al. (2003)

2.5.3.2 Enzyme activity was determined spectrophotometricaly.

2.5.3.3 Peroxidase activity was measured by using a guaiacol assay Angelini et al. (1990).

2.5.3.4 Catalase activity was measured by hydrogen peroxide assay based on formation of its stable complex with ammonium molibdate (Goth, 1991). $0.2 \mathrm{ml}$ of plant extract was incubated in $1 \mathrm{ml}$ reaction mixture containing $65 \mathrm{mM}$ hydrogen peroxide in $60 \mathrm{mM}$ potassium phosphate buffer, $\mathrm{pH} 7.4$ at $25^{\circ} \mathrm{C}$ for $4 \mathrm{~min}$. The enzymatic reaction was stopped with $1 \mathrm{ml}$ of $32.4 \mathrm{mM}$ ammonium molibdate and the concentration of the yellow complex of molibdate and hydrogen peroxide was measured at $405 \mathrm{~nm}$. Activity was expressed on a fresh mass basis (Units mg protein ${ }^{-1} \mathrm{FW}$ ).

\subsubsection{Extraction and purification of IAA and ABA}

Extraction, purification and quantitative determination of free and bound IAA and ABA were done, with minor modifications, according to the methods of Rastegar et al. (2011). Spectrophotometric techniques were used to determine the amounts of IAA and ABA. One gram fresh weight of each sample was taken and extracted with $60 \mathrm{ml}$ of methanol: chloroform: $2 \mathrm{~N}$ ammonium hydroxide mixture $(12: 5: 3 \mathrm{v} / \mathrm{v} / \mathrm{v})$. Each extract $(60 \mathrm{ml})$ was kept in a bottle in deep freeze for further analysis. Extract was then treated with $25 \mathrm{ml}$ of distilled water and the chloroform phase was discarded. The water-methanol phase was evaporated. The water phase was adjusted to the extract $\mathrm{pH}$ value of 2.5 or 7 or 11 with $1 \mathrm{~N} \mathrm{HCl}$ or $1 \mathrm{~N} \mathrm{NaOH}$ respectively and $15 \mathrm{ml}$ ethyl acetate was added at each of three steps. This procedure provided the isolation of free-form IAA and ABA 
from the extraction solvent. After an incubation period of 1 hour at $70{ }^{\circ} \mathrm{C}$, the same procedure was used for the isolation of bound-form of IAA and ABA from the extraction solvent. Evaporation of ethyl acetate was performed at $45^{\circ} \mathrm{C}$ using a roteevaporator system (B.chi Instruments). Thin-layer chromatography (TLC) was done using silica gel GF254 (Merck Chemicals, Germany) according to the method of Rastegar et al., (2011). TLC separated IAA and ABA were isolated from the glass plaques according to the standard synthetic IAA and $\mathrm{ABA} R f$ values. IAA and $\mathrm{ABA}$ were dissolved in $2 \mathrm{ml}$ of methanol for filtration and separation from silica using cotton-glass filled transferring pipettes. Spectrophotometeric assay was done at $280 \mathrm{~nm}$ for IAA and $263 \mathrm{~nm}$ for ABA and for all standard synthetic IAA and ABA and isolation samples.

2.5.5 Determination of potassium and sodium concentration was according to Creser and Parsons, (1979). This solution became transparent and used for determinations of $\mathrm{K}$ and $\mathrm{Na}$ concentrations by emission flame photometer (model 129, Shanghai Lingguang int. trade co., ltd.)

2.5.6 Determination of chloride concentration Chloride $\left(\mathrm{Cl}^{-}\right)$in plant tissue extracts was determined by potentiometric titration. With use $0.2 \mathrm{~g}$ of dried ground leaf tissue and addition of $50 \mathrm{ml} 2 \%$ acetic acid with shacking through 30 min and filtered by Whatman No.1, tritrated against $0.01 \mathrm{~N}$ silver nitrate using potassium chromate as an indicator to a bricked end point (Kalra, 1998).

\subsection{Statistical analysis}

Randomized completely block design of two date palm cultivars and five treatments of calcium replicated three times were used to conduct the experiment. Experimental data on all variables were subjected to analysis of variance (ANOVA) procedures using a statistical package, SPSS version 16.0 (SPSS, Chicago, IL). Revised Least Significant Differences (R.L.S.D.) among treatments was considered at the $P \leq 0.05$ levels.

\section{RESULTS AND DISCUSSION}

\subsection{Effect of calcium on plant height, leaf area, total chlorophyll and RWC under salt stress}

Results presented in Table 1 revealed that calcium treatments significantly $(P \leq 0.05)$ increased the height and leaf area of offshoots compared with control. Using polixal at $30 \mathrm{ml}$ offshoot $^{-1}$ to Berhi cultivar gave the highest values of height and leaf area $\left(34.3 \mathrm{~cm}, 1.20 \mathrm{~m}^{2}\right)$, respectively, whereas control with Sayer cultivar recorded the lowest value in this respect $\left(11.3 \mathrm{~cm}, 0.7 \mathrm{~m}^{2}\right)$, respectively. However, the increase of growth may be attributed to the expansion of cells and activation of photosynthesis by increased total chlorophyll and RWC, proline concentration and peroxidase activity. Protective role common to concentration, of $\mathrm{Ca}^{+2}$ might be attributed to its role in the maintenance of the structural integrity of the plasma membrane and thus controlling the uptake of $\mathrm{Na}^{+}$and $\mathrm{Cl}$. Larkindale and Knight, (2002) suggested that calcium role is in protecting against oxidative damage by the protection of calcium channel blockers and calmodulin inhibitors under heat stress. During our experiments field temperature was up to $40{ }^{\circ} \mathrm{C}$. The resultant transient $\mathrm{Ca}^{2+}$ increase caused potential stress signal transduction and led to salt adaptation (Gul and Ajmal, 2006). Effect of calcium on height of the plant is in agreement with that obtained by Al-Whaibi et al., (2011) on wheat plant and effect of calcium on leaf area is in concordance with findings of El-Khawaga, (2013) on date palm. The increased offshoot height of Berhi cultivar may be attributed to its ability to restrict $\mathrm{Cl}^{-}$movement into the shoot more effectively than the Sayer cultivar. Thus, the concentrations of potentially harmful $\mathrm{Cl}^{-}$ions would be lower in the photosynthetically active tissues, or different in the genotype of vigorous the growth rate in term of Berhi cultivar, and the largest in Sayer cultivar. Table 1 reveals that the total chlorophyll content and RWC of leaves was increased by polixal at $30 \mathrm{ml}$ offshoot $^{-1}$. Analysis of Berhi cultivar gave the highest values of total chlorophyll and RWC (1.8 mg.g $\left.{ }^{-1}, 6.5 \mathrm{~g}, 83.7 \%\right)$, respectively, whereas control with Sayer cultivar gave the lowest value in this respect $\left(0.8 \mathrm{mg} . \mathrm{g}^{-1}\right.$, 
$65.3 \%) . \mathrm{Ca}^{2+}$ retarded the loss of chlorophyll, protein and intercellular space, suggesting that the ion plays a regulatory role in maintaining and controlling membrane structure and function (Hepler, 2005). From those studies and our results suggesting that the $\mathrm{Ca}^{2+}$ plays a regulatory role in maintaining of chlorophyll, it acts as an antioxidant system regulator by increase proline in chloroplasts for scavenging of ROS. Effect of $\mathrm{Ca}^{2+}$ is in agreement with that obtained by Jafari et al., (2009) on sorghum plant by calcium. The role of
$\mathrm{Ca}^{2+}$ in increased relative water content might be attributed to its ability to regulate the compatible solutes and osmotic adjustment, subsequently increasing turgor. Jafari et al. (2009) suggested that the protective effect of $\mathrm{Ca}^{2+}$ in salinized plants is probably due to its role in maintaining membrane integrity, because one of the primary effects of salt stress is a disruption of membrane integrity caused by displacement of $\mathrm{Ca}^{2+}$ from the cell surface by $\mathrm{Na}^{+}$.

Table 1: Averages of plant height $(\mathrm{cm})$, leaf area $\left(\mathrm{m}^{2}\right)$, total chlorophyll $\left(\mathrm{mg} \mathrm{g}^{-1}\right)$ and RWC (\%) of Berhi and Sayer

\begin{tabular}{|c|c|c|c|c|c|}
\hline Cultivars & Treatments & Plant height $(\mathrm{cm})$ & Leaf area $\left(\mathrm{m}^{2}\right)$ & $\begin{array}{l}\text { Total chlorophyll } \\
\qquad\left(\mathrm{mg} \mathrm{g}^{-1}\right)\end{array}$ & $\begin{array}{l}\text { RWC } \\
(\%)\end{array}$ \\
\hline \multirow[t]{5}{*}{ Berhi } & $\mathrm{C}$ & $15.0 \pm 5.0^{\mathrm{d}}$ & $0.8 \pm 0.02^{\mathrm{ef}}$ & $0.9 \pm 0.02^{\mathrm{fg}}$ & $67.3 \pm 1.2^{\mathrm{d}}$ \\
\hline & $\mathrm{P} 1$ & $26.6 \pm 1.5^{b}$ & $0.9 \pm 0.06^{\mathrm{cde}}$ & $1.4 \pm 0.05^{\mathrm{b}}$ & $74.3 \pm 0.7^{\mathrm{c}}$ \\
\hline & $\mathrm{P} 2$ & $34.3 \pm 2.0^{\mathrm{a}}$ & $1.2 \pm 0.16^{\mathrm{a}}$ & $1.8 \pm 0.03^{\mathrm{a}}$ & $83.7 \pm 0.8^{\mathrm{a}}$ \\
\hline & $\mathrm{R} 1$ & $25.0 \pm 2.0^{\mathrm{bc}}$ & $0.9 \pm 0.04^{\mathrm{cde}}$ & $1.0 \pm 0.05^{\mathrm{de}}$ & $78.9 \pm 0.5^{b}$ \\
\hline & $\mathrm{R} 2$ & $31.6 \pm 2.5^{\mathrm{ab}}$ & $1.1 \pm 0.23^{\mathrm{ab}}$ & $1.1 \pm 0.0^{\mathrm{c}}$ & $83.3 \pm 0.5^{\mathrm{a}}$ \\
\hline \multirow[t]{5}{*}{ Sayer } & $\mathrm{C}$ & $11.3 \pm 1.5^{\mathrm{d}}$ & $0.7 \pm 0.0^{\mathrm{f}}$ & $0.8 \pm 0.07^{\mathrm{g}}$ & $65.3 \pm 0.9^{\mathrm{e}}$ \\
\hline & $\mathrm{P} 1$ & $21.6 \pm 2.5^{\mathrm{c}}$ & $0.9 \pm 0.01^{\text {cde }}$ & $1.0 \pm 0.00^{\mathrm{d}}$ & $75.0 \pm 1.2^{\mathrm{c}}$ \\
\hline & $\mathrm{P} 2$ & $30.3 \pm 0.57^{\mathrm{ab}}$ & $1.0 \pm 0.02^{\mathrm{bc}}$ & $1.1 \pm 0.02^{\mathrm{c}}$ & $79.5 \pm 0.6^{\mathrm{b}}$ \\
\hline & $\mathrm{R} 1$ & $25.0 \pm 2.0^{\mathrm{bc}}$ & $0.8 \pm 0.01^{\mathrm{def}}$ & $0.9 \pm 0.02^{\mathrm{ef}}$ & $74.6 \pm 0.9^{c}$ \\
\hline & $\mathrm{R} 2$ & $28.6 \pm 2.0^{b}$ & $0.9 \pm 0.02^{\text {bcd }}$ & $0.9 \pm 0.02^{\mathrm{f}}$ & $78.1 \pm 0.6^{b}$ \\
\hline \multicolumn{2}{|c|}{ R.L.S.D. $(P \leq 0.05)$} & 4.1 & 0.16 & 0.06 & 1.4 \\
\hline
\end{tabular}

cultivars response to Ca-fertilisers under salt stress

Value represents mean \pm standard error of three replicates.

C: Foliar spray of Water as control, P1: Soil addition of POLIXAL 20-8* (15ml offshoot $\left.{ }^{-1}\right)$, P2: Soil addition of POLIXAL 20-8 (30 ml offshoot $\left.{ }^{-1}\right)$, R1: Foliar spray of Rexene ca 10* (1000 ppm offshoot $\left.{ }^{-1}\right)$, R2: Foliar spray of Rexene ca 10 (2000 ppm offshoot $\left.{ }^{-1}\right)$

\subsection{Effect of calcium on proline concentration, POD and CAT activities, IAA and ABA under salt stress}

Table 2 reveals that calcium treatments resulted in significantly $(P \leq 0.05)$ higher proline concentration and peroxidase activity of treated leaves compared to control. The application of polixal $30 \mathrm{ml}$ offshoot $^{-1}$ to Berhi cultivar led to increase proline concentration and peroxidase activity (15.4 mg g $\mathrm{g}^{-1}, 7.2$ unit $\mathrm{mg}^{-1} \mathrm{FW}$ ), respectively, compared with control to Sayer cultivar which had the lowest values in this respect (9.1 $\mathrm{mg} \mathrm{g}^{-1}, 4.2$ unit $\mathrm{mg}^{-1} \mathrm{FW}$ ), when using polixal at $30 \mathrm{ml} \mathrm{offshoot}^{-1}$, Experiment with Berhi cultivar gave the lowest value of catalase activity ( 0.7 units mg protein ${ }^{-1} \mathrm{FW}$ ) compared to control to Sayer cultivar, which gave the highest value of catalase activity (2.3 units $\mathrm{mg}$ protein $^{-1} \mathrm{FW}$ ). Effect of calcium in the alleviation of salt stress and the increase of proline reflects the ability of salttolerant offshoot to prevent damage of ROS by maintaining better enzymatic (POD and CAT) and non-enzymatic (proline) defense systems. Proline plays a major role in osmoadaptation through an increase in osmotic stress that shifts the dominant osmolyte from glutamate to proline (Tripathi et al., 1998). From the results in this work, it seems that proline might confer salt stress tolerance to 
offshoots by increasing the antioxidant system and osmotic adjustment mediator. Thus proline facilitates water uptake. Effect of calcium is in agreement with that obtained by Al-Whaibi et al., (2011) on wheat plant by used calcium. Also, it has been commonly reported that salt stress is one of the major causes of oxidative damage to plant tissues. Though, plants can reduce the damaging effects of reactive oxygen species by developing a physiologically powerful defense system together with antioxidant enzymes like POD and CAT (Rao et al. 2013). Salinity intensity leads to reduce water accessibility and/or absorption and therefore lowered leaf turgor and, at last, leads to stomata closure (Azizpour et al. 2010). $\mathrm{CO}_{2}$ attainment influenced by stomata closure is a basis for fluctuations and imbalances in ongoing light reactions and $\mathrm{CO}_{2}$ fixation. The final result of these nonstandard conditions would be reduced $\mathrm{NADP}^{+} / \mathrm{NADPH}, \mathrm{H}^{+}$ratio and increased $\mathrm{ROS}$ production (Esfandiari et al. 2007). Our results showed that peroxidase to activity increased more in salt-stressed plants supplied with calcium than salt stress alone, whereas catalase activity decreased in calcium treatments. The mechanism of CAT and POD activities regulated by external calcium is still vague. Whereas peroxidase has ability to stimulate growth and improve tolerance to salt stress, its primary function is to oxidize molecules at the expense of hydrogen peroxide. They play a major role in four physiological processes; auxin metabolism, lignin fortification, defense mechanisms against pathogens and some respiratory processes (Baaziz, 1989), it is also a part of antioxidant defense systems which work in concert to control cascades of uncontrolled oxidation and protect plant cells from oxidative damage by scavenging of ROS. Also, data in Table 2 indicate that two date palm cultivars had significant differences in IAA content. The maximum value was presented in using polixal at $30 \mathrm{ml} \mathrm{offshoot}{ }^{-1}$ to Sayer cultivar $\left(84.6 \mu \mathrm{g} \mathrm{g}^{-1}\right)$, whereas control of Berhi cultivar recorded the minimum value in this respect $\left(43.3 \mu \mathrm{g} \mathrm{g}^{-1}\right)$. While the results showed a reverse effect on the content of $\mathrm{ABA}$ that the treatment of polixal at $30 \mathrm{ml}$ offshoot $^{-1}$ to Berhi cultivar gave the lowest values of ABA content $\left(54.2 \mu \mathrm{g} \mathrm{g}^{-1}\right)$, and control of Sayer cultivar recorded the highest value in this respect $\left(85.8 \mu \mathrm{g} \mathrm{g}^{-1}\right)$. The positive action of calcium compounds on increased endogenous IAA and decreased endogenous $\mathrm{ABA}$ content might be attributed to mitigated the adverse effects of salt stress on offshoots by osmoregulation which is possibly mediated by increased production of carbohydrates (data not shown) as well as increased proline concentration by regulating the membrane stability, photosynthetic pigments and modify the balance between these hormones and metabolites. Further, protection under salt stress was achieved through enhanced activities of antioxidant enzymes, to POD and CAT. Thus enhanced recover and stimulate growth. These phytohormones can positively or adversely affect preceding plant growth, while interacting with each other (Fahad et al. 2014). One of the fast and sensitive auxin-induced reactions is an increase of $\mathrm{Ca}^{2+}$ cytosolic concentration, which is suggested to be dependent on the activation of $\mathrm{Ca}^{2+}$ influx through the plasma membrane and auxin increases plasma membrane permeability to $\mathrm{Ca}^{2+}$ (Kirpichnikova et al. 2014). The role of calcium in increase IAA and decrease ABA content might be to IAA acts as a signal for increases plasma membrane permeability to $\mathrm{Ca}^{2+}$, thus maintains and modifies the balance between these hormones for the purpose of reducing the damage by salinity and stimulate growth by alleviation of ABA content. 
Table 2: Averages of proline ( $\mathrm{mg} \mathrm{g}^{-1}$ ), POD (unit $\mathrm{mg}^{-1} \mathrm{FW}$ ), CAT (unit mg protein ${ }^{-1} \mathrm{FW}$ ), IAA ( $\mu \mathrm{g} \mathrm{g}^{-1}$ ) and ABA $\left(\mu \mathrm{g} \mathrm{g}^{-1}\right)$ of Berhi and Sayer cultivars response to Ca-fertilisers under salt stress

\begin{tabular}{|c|c|c|c|c|c|c|}
\hline Cultivars & Treatments & $\begin{array}{l}\text { Proline } \\
\left(\mathrm{mg} \mathrm{g}^{-1}\right)\end{array}$ & $\begin{array}{c}\text { POD } \\
\text { (Unit } \\
\left.\mathrm{mg}^{-1} \mathrm{FW}\right)\end{array}$ & $\begin{array}{c}\text { CAT } \\
\text { (Unit mg } \\
\left.\text { protein }^{-1} \mathrm{FW}\right)\end{array}$ & $\begin{array}{c}\text { IAA } \\
\left(\mu \mathrm{g} \mathrm{g}^{-1}\right)\end{array}$ & $\begin{array}{c}\mathrm{ABA} \\
\left(\mu \mathrm{g} \mathrm{g}^{-1}\right)\end{array}$ \\
\hline \multirow[t]{5}{*}{ Berhi } & $\mathrm{C}$ & $12.4 \pm 0.04^{\mathrm{d}}$ & $5.1 \pm 0.11^{\mathrm{c}}$ & $1.3 \pm 0.10^{\mathrm{c}}$ & $43.3 \pm 3.9^{\mathrm{e}}$ & $80.6 \pm 5.8^{a b}$ \\
\hline & $\mathrm{P} 1$ & $13.3 \pm 0.13^{\mathrm{c}}$ & $6.6 \pm 0.21^{\mathrm{b}}$ & $0.9 \pm 0.02^{\mathrm{ab}}$ & $70.7 \pm 4.5^{\mathrm{d}}$ & $67.9 \pm 3.0^{\mathrm{cd}}$ \\
\hline & P2 & $15.4 \pm 0.35^{\mathrm{a}}$ & $7.2 \pm 0.23^{\mathrm{a}}$ & $0.7 \pm 0.01^{\mathrm{a}}$ & $81.0 \pm 2.0^{\mathrm{ab}}$ & $54.2 \pm 4.3^{\mathrm{e}}$ \\
\hline & $\mathrm{R} 1$ & $13.4 \pm 0.25^{\mathrm{c}}$ & $6.5 \pm 0.08^{\mathrm{b}}$ & $1.3 \pm 0.05^{\mathrm{c}}$ & $73.8 \pm 2.8^{\mathrm{cd}}$ & $77.1 \pm 4.5^{b}$ \\
\hline & $\mathrm{R} 2$ & $14.9 \pm 0.34^{\mathrm{b}}$ & $7.1 \pm 0.06^{\mathrm{a}}$ & $1.2 \pm 0.10^{\mathrm{bc}}$ & $78.3 \pm 1.9^{\mathrm{bc}}$ & $63.2 \pm 3.3^{\mathrm{d}}$ \\
\hline \multirow[t]{5}{*}{ Sayer } & $\mathrm{C}$ & $9.1 \pm 0.07^{\mathrm{h}}$ & $4.2 \pm 0.18^{\mathrm{e}}$ & $2.3 \pm 0.09^{\mathrm{e}}$ & $46.1 \pm 1.6^{\mathrm{e}}$ & $85.8 \pm 3.4^{\mathrm{a}}$ \\
\hline & $\mathrm{P} 1$ & $11.1 \pm 0.01^{\mathrm{g}}$ & $4.6 \pm 0.03^{d}$ & $1.6 \pm 0.07^{\mathrm{d}}$ & $73.6 \pm 2.0^{\mathrm{d}}$ & $71.5 \pm 4.1^{b c}$ \\
\hline & $\mathrm{P} 2$ & $11.2 \pm 0.06^{\mathrm{fg}}$ & $5.0 \pm 0.07^{\mathrm{c}}$ & $1.3 \pm 0.11^{\mathrm{c}}$ & $84.6 \pm 2.0^{\mathrm{a}}$ & $66.9 \pm 2.9^{\mathrm{cd}}$ \\
\hline & $\mathrm{R} 1$ & $11.5 \pm 0.12 \mathrm{f}$ & $4.6 \pm 0.02^{\mathrm{d}}$ & $1.8 \pm 0.57 \mathrm{de}$ & $69.6 \pm 2.9^{\mathrm{d}}$ & $69.9 \pm 2.8^{\mathrm{c}}$ \\
\hline & $\mathrm{R} 2$ & $11.9 \pm 0.12^{\mathrm{e}}$ & $5.0 \pm 0.11^{\mathrm{c}}$ & $2.1 \pm 0.26^{\mathrm{e}}$ & $81.8 \pm 1.5^{\mathrm{ab}}$ & $68.4 \pm 1.8^{\mathrm{cd}}$ \\
\hline \multicolumn{2}{|c|}{ R.L.S.D. $(P \leq 0.05)$} & 0.3 & 0.2 & 0.3 & 4.6 & 6.4 \\
\hline
\end{tabular}

Value represents mean \pm standard error of three replicates.

C: Foliar spray of Water as control, P1: Soil addition of POLIXAL 20-8* $\left(15 \mathrm{ml}_{\text {offshoot }}{ }^{-1}\right)$, P2: Soil addition of POLIXAL 20-8 (30 ml offshoot $\left.{ }^{-1}\right)$, R1: Foliar spray of Rexene ca 10* (1000 ppm offshoot $\left.{ }^{-1}\right)$, R2: Foliar spray of Rexene ca 10 (2000 ppm offshoot $\left.{ }^{-1}\right)$

\subsection{Effect of calcium on $\mathrm{Na}^{+}, \mathrm{K}^{+}, \mathrm{Cl}^{-}$and $\mathrm{Na} / \mathrm{K}$ ratio under salt stress}

Results presented in Table 3 revealed that calcium treatments significantly $(P \leq 0.05)$ decreased $\mathrm{Na}^{+}$ and $\mathrm{Cl}^{-}$content of leaves compared with control. The using of polixal at $30 \mathrm{ml}$ offshoot ${ }^{-1}$ to Berhi cultivar gave the lowest values of $\mathrm{Na}^{+}$and $\mathrm{Cl}^{-}$ content $\left(4.0 \mathrm{mg} \mathrm{g}^{-1}, 4.0 \mathrm{mg} \mathrm{g}^{-1}\right)$, respectively, whereas, control treatment of Sayer cultivar recorded the highest value in this respect $(11.6 \mathrm{mg}$ $\left.\mathrm{g}^{-1}, 15.1 \mathrm{mg} \mathrm{g}^{-1}\right)$, respectively. Also, data in Table 3 showed that the using polixal at $30 \mathrm{ml} \mathrm{offshoot}^{-1}$ to Sayer cultivar gave the highest values of $\mathrm{K}^{+}$ content $\left(18.0 \mathrm{mg} \mathrm{g}^{-1}\right)$ compared with control treatment to Berhi cultivar $\left(10.6 \mathrm{mg} \mathrm{g}^{-1}\right)$. Calcium treatments significantly increased $\mathrm{K}^{+} / \mathrm{Na}^{+}$ratio of leaves compared with control. Using polixal at $30 \mathrm{ml}^{\text {offshoot }}{ }^{-1}$ to Berhi cultivar gave the highest values of $\mathrm{K}^{+} / \mathrm{Na}^{+}$ratio (4.0) compared with control treatment of Sayer cultivar (1.2). Increasing $\mathrm{K}^{+}$ concentrations under saline conditions may help to decrease sodium uptake required for maintaining the osmotic balance (Tuteja and Mahajan, 2007). Grattan and Grieve, (1999) reported that addition of $\mathrm{Ca}$ restored the levels of N, P, K in tissues. Our results cleared that increasing $\mathrm{K}^{+}$related with increase $\mathrm{Na}^{+}$in both cultivars and the cultivar is more salt tolerant when accumulates less $\mathrm{Na}^{+}, \mathrm{Cl}^{-}$ and $\mathrm{K}^{+}$ions. The role of calcium in decreased $\mathrm{Na}^{+}$ content and promoted uptake of potassium, thus increased $\mathrm{K}^{+} / \mathrm{Na}^{+}$ratio might be attributed to that $\mathrm{Ca}^{2+}$ promoted the uptake of $\mathrm{K}^{+}$in the presence of sodium. Thus, $\mathrm{Ca}^{2+}$ by some mechanisms imparts selectivity to the ion transport process (Hepler, 2005). $\mathrm{Ca}^{2+}$ decreased roots $\mathrm{Na}^{+}$accumulation, increased shoots $\mathrm{K}^{+}$accumulation, and enhanced the selective absorption and transport capacity for $\mathrm{K}^{+}$over $\mathrm{Na}^{+}$in thr plant (Wu and Wang, 2012). The obtained results go in line with the findings of Zekri and Parsons, (1990) on sour orange seedlings. $\mathrm{K}^{+} / \mathrm{Na}^{+}$and $\mathrm{Ca} / \mathrm{Na}$ ratios are useful indicators of the degree of plant resistance to salinity that a greater degree of salinity tolerance in plants are associated with a more efficient system for selective uptake of $\mathrm{K}^{+}$and/or $\mathrm{Ca}^{2+}$ over $\mathrm{Na}^{+}$ (Wu and Wang, 2012; Wu et al. 2013). It is suggested that $\mathrm{K}^{+}$and $\mathrm{Ca}^{2+}$ play key roles in several physiological processes, such as stabilization of membranes and control of enzyme 
activity, $\mathrm{Na}^{+}$does not function as a macro-nutrient, and thus the substitution of $\mathrm{K}^{+}$by $\mathrm{Na}^{+}$and the decrease in $\mathrm{Ca}^{2+}$ concentration may cause ion imbalances (Tuna et al. 2007). Therefore, control of $\mathrm{Na}^{+}$accumulation, and high $\mathrm{K}^{+} / \mathrm{Na}^{+}$and $\mathrm{Ca}^{2+} / \mathrm{Na}^{+}$ratios may enhance salinity tolerance in plants (Wu et al. 2013). However, Berhi cultivar had higher $\mathrm{K}^{+} / \mathrm{Na}^{+}$ratio than Sayer cultivar. This was due to the result of both a higher $\mathrm{K}^{+}$and a lower $\mathrm{Na}^{+}$concentration in Berhi cultivar, indicating that Berhi cultivar has a better capacity to maintain intracellular $\mathrm{K}^{+}$and $\mathrm{Na}^{+}$homeostasis, and thus is subjected to less damage under salt stress. The relatively stronger tolerance of this cultivar to salinity may be related to the ability of plants to accumulate high levels of proline, RWC and maintain the high ratio of $\mathrm{K}^{+} / \mathrm{Na}^{+}$and regulate levels of IAA to ABA.

Table 3: Averages of $\mathrm{Na}^{+}, \mathrm{K}^{+}, \mathrm{Cl}^{-}\left(\mathrm{mg} \mathrm{g}^{-1}\right)$ and $\mathrm{K}^{+} / \mathrm{Na}^{+}$ratio of Berhi and Sayer cultivars response to Ca-fertilisers under salt stress

\begin{tabular}{|c|c|c|c|c|c|}
\hline Cultivars & Treatments & $\begin{array}{c}\mathrm{Na} \\
\left(\mathrm{mg} \mathrm{g}^{-1}\right)\end{array}$ & $\begin{array}{c}\mathrm{K} \\
\left(\mathrm{mg} \mathrm{g}^{-1}\right)\end{array}$ & $\begin{array}{c}\mathrm{Cl} \\
\left(\mathrm{mg} \mathrm{g}^{-1}\right)\end{array}$ & $\begin{array}{c}\mathrm{K} / \mathrm{Na} \\
\text { Ratio }\end{array}$ \\
\hline Berhi & $\mathrm{C}$ & $8.3 \pm 1.7^{\mathrm{b}}$ & $10.6 \pm 2.2^{\mathrm{b}}$ & $9.6 \pm 0.5^{\mathrm{de}}$ & $1.3 \pm 0.4^{\mathrm{c}}$ \\
& $\mathrm{P} 1$ & $5.5 \pm 0.7^{\mathrm{a}}$ & $11.0 \pm 0.6^{\mathrm{d}}$ & $6.1 \pm 0.7^{\mathrm{b}}$ & $2.0 \pm 0.1^{\mathrm{c}}$ \\
& $\mathrm{P} 2$ & $4.0 \pm 1.1^{\mathrm{a}}$ & $15.6 \pm 0.5^{\mathrm{bc}}$ & $4.0 \pm 0.5^{\mathrm{a}}$ & $4.0 \pm 0.9 \mathrm{a}$ \\
& $\mathrm{R} 1$ & $4.9 \pm 1.0^{\mathrm{a}}$ & $12.3 \pm 1.5^{\mathrm{d}}$ & $8.0 \pm 0.5^{\mathrm{c}}$ & $2.5 \pm 0.8^{\mathrm{bc}}$ \\
& $\mathrm{R} 2$ & $4.8 \pm 1.0^{\mathrm{a}}$ & $14.8 \pm 0.8^{\mathrm{bc}}$ & $6.0 \pm 0.5^{\mathrm{b}}$ & $3.1 \pm 0.4^{\mathrm{ab}}$ \\
Sayer & $\mathrm{C}$ & $11.6 \pm 2.0^{\mathrm{c}}$ & $14.7 \pm 0.6^{\mathrm{c}}$ & $15.1 \pm 1.0^{\mathrm{g}}$ & $1.2 \pm 0.2^{\mathrm{c}}$ \\
& $\mathrm{P} 1$ & $6.8 \pm 0.5^{\mathrm{b}}$ & $15.0 \pm 2.0^{\mathrm{bc}}$ & $10.0 \pm 0.5^{\mathrm{e}}$ & $2.2 \pm 0.4^{\mathrm{bc}}$ \\
& $\mathrm{P} 2$ & $6.0 \pm 1.0^{\mathrm{ab}}$ & $18.0 \pm 1.0^{\mathrm{a}}$ & $8.9 \pm 0.6^{\mathrm{cd}}$ & $3.0 \pm 0.4^{\mathrm{b}}$ \\
& $\mathrm{R} 1$ & $8.0 \pm 1.0^{\mathrm{b}}$ & $15.5 \pm 1.7^{\mathrm{bc}}$ & $11.5 \pm 0.5^{\mathrm{f}}$ & $1.9 \pm 0.4^{\mathrm{c}}$ \\
& $\mathrm{R} 2$ & $6.6 \pm 0.5^{\mathrm{b}}$ & $17.1 \pm 1.0^{\mathrm{ab}}$ & $10.5 \pm 0.5^{\mathrm{ef}}$ & $2.6 \pm 0.4^{\mathrm{bc}}$ \\
\hline \multicolumn{2}{|r|}{ R.L.S.D. $(P \leq 0.05)$} & $2.0^{2}$ & $2.3^{2}$ & $1.0^{2}$ & 0.9 \\
\hline
\end{tabular}

Value represents mean \pm standard error of three replicates.

C: Foliar spray of Water as control, P1: Soil addition of POLIXAL 20-8* (15ml offshoot $\left.{ }^{-1}\right)$, P2: Soil addition of POLIXAL 20-8 (30 ml offshoot $\left.{ }^{-1}\right)$, R1: Foliar spray of Rexene ca 10* (1000 ppm offshoot $\left.{ }^{-1}\right)$, R2: Foliar spray of Rexene ca 10 (2000 ppm offshoot ${ }^{-1}$ )

\section{CONCLUSIONS}

The study involving calcium with different concentrations and type of fertilisers indicated that the addition of POLIXAL 20-8 (30 ml offshoot $\left.{ }^{-1}\right)$ to the soil is more effective than foliar spray of Rexene ca 10 (2000 ppm offshoot $\left.{ }^{-1}\right)$ in all the parameters of study. We can deduce from the results that calcium effect was due to the protection against oxidative damage by protecting calcium channel blockers and calmodulin inhibitors under salt and heat stress. Also, maybe Berhi cultivar is more salt stress tolerant than Sayer cultivar by maintaining a high ratio of $\mathrm{K}^{+} / \mathrm{Na}^{+}$and regulating levels of IAA to ABA. We suggest also that there is a common link between the peroxidase enzyme and calcium ion in stimulating growth and improving salt stress tolerance. 


\section{REFERENCES}

Ahmed, F. F. and Morsy, M. H. 1999. New methods for measuring leaf area in different fruit species, Minia, J. Agric. Res. Dev.19: 97-105.

Al-Whaibi, M. H; Manzer, H S. and Mohammed, O. B. 2011. Salicylic acid calcium-induced protection of wheat againsts salinity, Protoplasma ;249(3):769778.Doi: 10.1007/s00709-011-0322-1

Angelini, R.; Manes, F. and Federico, R.1993. Spatial and functional correlation between diamine-oxidase and peroxidase activitys and their dependence upon de-etiolation and wounding in chick-pea stems, planta, 182 (1): 89-96.

Azizpour, K; M. R. Shakiba, K. N. Sima, K, H. Alyari, M. Moghaddam, E. Esfandiari and M. Pessarakli, 2010."Physiological Response of Spring Durum Wheat Genotypes to Salinity," Journal of Plant Nutrition, $33 \quad$ (6): 859-873. Doi: $10.1080 / 01904161003654097$

Baaziz, M. 1989. The activity and preliminary characterization of peroxidases in leaves of cultivars of date palm, Phoenix dactylifera L., New Phytol., 111: 401- 411. Doi: 10.1111/j.14698137.1989.tb00703.x

Cramer, G. R. (2002). Sodium-calcium interactions under salinity stress In: Salinity. EnvironmentPlants- Molecules. Eds. A. Läuchli, and U. Lüttge, Kluwer Academic Publishers.

Cresser, M. S. and Parsons, J. W. 1979. Sulphuric perchloric acid digestion of plant material for the determination of nitrogen, phosphorus, potassium, calcium and magnesium. Analytical Chimica Acta 109: 431 - 436. Doi: 10.1016/S00032670(01)84273-2

El-Khawaga, A.S. 2013. Effect of Anti-salinity Agents on growth and fruiting of Different Date Palm Cultivars, Asian J. of Crop science 5 (1): 65-80.

Esfandiari, E.; F. Shekari, F. Shekari and M. Esfandiari, 2007. The Effect of Salt Stress on Antioxidant Enzymes Activity and Lipid Peroxidation on the Wheat Seedling," Notulae Botanicae Horti Agrobotanici Cluj-Napoca, 35 (1): 48-56.

Fahad ,S.; S. Hussain; A. Bano; S. Saud; S. Hassan; D. Shan; F. Ahmed Khan; F. Khan; Y. Chen; C. Wu; M. Adnan Tabassum;M. Chun; M. Afzal; A. Jan; M. T. Jan and J. Huang, 2014. Potential role of phytohormones and plant growth-promoting rhizobacteria in abiotic stresses: consequences for changing environment, Environ Sci Pollut Res: 115 .
Goth, L. 1991. Asimple method for determination of serum Catalase and revision of reference range. Clin. Chim. Acta., 196: 143-152. Doi: 10.1016/0009-8981(91)90067-M

Grattan, S. R. and Grieve, C. M. 1999. Salinity mineral nutrient relations in horticultural crops. Sci Hortic 78: 127-157. Doi: 10.1016/S0304-4238(98)001927

Gul, B. and M. Ajmal, K, 2006. Role of Calcium in alleviation salinity effects in coastal Halophytes in: M. A. Khan and D. J. Weber (eds.), Ecophysiology of High Salinity Tolerant Plants, Springer. Printed in the Netherlands: 107-114

Hasegawa P., Bressan R., Zhu J., Bohnert H. 2000. Plant cellular and molecular responses to high salinity. in: Torabi, Masoud: R. A. Halim; A. Mokhtarzadeh and Y. Miri (ed). Physiological and Biochemical Responses of Plants in Saline Environment in: Roychowdhury, R. (Ed.), Crop Biology and Agriculture in Harsh Environments, LAP LAMBERT Academic Publishing: 47-80.

Hepler, Peter K. 2005. Calcium: A Central Regulator of Plant Growth and Development, Plant Cell; 17; 2142-2155. Doi: 10.1105/tpc.105.032508

Irigoyen, J. J., Emerich, D. W. Sanchez- Diaz, M. 1992. Water stress induce changes in concentrations of proline and total soluble sugars in nodulated alfalfa (Medicago sativa) plants. Physiol Plant 84: 55- 60. Doi: 10.1111/j.1399-3054.1992.tb08764.x

Jafari, M. H. S.; Kafi, M. and Astaraie, A. 2009. Interactive effect of $\mathrm{NaCl}$ induced salinity, Calcium and Potassium on Physiomorphological Traits of Sorghum (Sorghum sorghumbicolor L.), Pak. J. Bot., 41(6): 3053- 3063.

Kalra, Y. P.1998. Hand book of methods for plant analysis. soil and plant analysis council, inc. extractable chloride, nitrate, orthophosphate, potassium, and sulfate - sulfurin plant tissue: $2 \%$ acetic and extraction. Robert O. Miller. by Taylor and Francis Group. LLC. P: $115-118$.

Kirpichnikova, Anastasia A.; Elena L. Rudashevskaya; Vladislav V. Yemelyanov and Maria F. Shishova, 2014. $\mathrm{Ca}^{2+}$-Transport through Plasma Membrane as a Test of Auxin Sensitivity, Plants, 3: 209-222. Doi: 10.3390/plants3020209

Larkindale, Jane and Knight, Marc R. 2002. Protection against Heat Stress-Induced Oxidative Damage in Arabidopsis Involves Calcium, Abscisic Acid, Ethylene, and Salicylic Acid, Plant Physiol. 128: 682-695. Doi: 10.1104/pp.010320 
Lichtenthaler, H. K., and A. R. Wellburn. 1983. Determinations of total carotenoids and chlorophylls a an b of leaf extracts in different solvents. Biochemical Society Transmycological 11: 591-593. Doi: 10.1042/bst0110591

Lindberg, S.; Md. A. Kader and V. Yemelyanov. 2012. Calcium Signalling in Plant Cells Under Environmental Stress, in: P. Ahmad and M.N.V. Prasad (eds.), Environmental Adaptations and Stress Tolerance 325 of Plants in the Era of Climate Change, Springer Science, Business Media: 325360 .

Louchli, A. and Grattan, S. R. (2007). Plant growth and development under salinity stress in: M. A. Jenks et al. (eds.), Advances in Molecular Breeding Toward Drought and Salt Tolerant Crops, Springer: 1-32. Doi: 10.1007/978-1-4020-5578-2 1

Luhova, L.; Lebeda, A. and Hederereova, p.p. 2003. Activitys of amino peroxidase, peroxidase and Catalase in seedlings of Pisum sativum L. under different light conditions, plant soil Environ.,49 (4): 151-157.

Rao, A.; Syed, D. A., Syed, M. S.; Shahid, I. A.; Asad Hussain, S., Syed, R. A.; Saima, S.; Fareed, K. and Atia, C. (2013). Potential Antioxidant Activities Improve Salt Tolerance in Ten Varieties of Wheat (Triticum aestivum L.), American Journal of Plant Sciences 4: 69-76. Doi: 10.4236/ajps.2013.46A010

Rastegar, S.; Rahemi,M. and Zargari, H. 2011.Changes in Endogenous Hormones in fruit during Growth and Development of Date Palm fruits, AmericanEurasian J. Agric. Environ. Sci., 11: 140-148.

Reddy, A.S.N. (2001). Calcium: silver bullet in signaling, Plant Science 160: 381-404. Doi: 10.1016/S0168-9452(00)00386-1
Tripathi AK, Mishra BM, Tripathi P. 1998. Salinity stress responses in plant growth promoting rhizobacteria. J Biosci 23:463-471. Doi: 10.1007/BF02936140

Tuna AL, Kaya C, Ashraf M, Altunlu H, Yokas I, Yagmur B. 2007. The effects of calcium sulphate on growth, membrane stability and nutrient uptake of tomato plants grown under salt stress. Environ Exp Bot 59: 173-178. 10.1016/j.envexpbot.2005.12.007

Türkan, I. and Demiral, T. 2009. Recent developments in understanding salinity tolerance, Environmental and Experimental Botany 67: 2-9. Doi: 10.1016/j.envexpbot.2009.05.008

Tuteja, N. and Mahajan, S. 2007. Calcium Signaling Network in Plants, Plant Signaling \& Behavior 2: 2, 79-85. Doi: $10.4161 /$ psb.2.2.4176

$\mathrm{Wu}$, G. and Wang, S. M. 2012. Calcium regulates $\mathrm{K}^{+} / \mathrm{Na}^{+}$homeostasis in rice (Oryza sativa L.) under saline conditions. Plant Soil Environ 58: 121-127.

Wu, G.; N. Liang; Rui-Jun Feng and Jing-Jing Zhang, 2013. Evaluation of salinity tolerance in seedlings of sugar beet (Beta vulgaris L.) cultivars using proline, soluble sugars and cation accumulation criteria, Acta Physiol Plant, 35: 2665-2674. Doi: 10.1007/s11738-013-1298-6

Zekri, M. and L. R. Parsons. 1990. Calcium Influences Growth and Leaf Mineral Concentration of Citrus under Saline Conditions, HORTSCIENCE 25(7): 784- 786.

Zhu, JK. 2001. Plant salt tolerance, Trends Plant Sci, 6: 66-71. Doi: 10.1016/S1360-1385(00)01838-0 